\title{
Strategic Corporate Social Responsibility by a Local Firm Against a Multinational Enterprise
}

\author{
Michael Kopel $^{1}$, Constantine Manasakis ${ }^{2(凶)}$, and Emmanuel Petrakis ${ }^{3}$ \\ 1 Institute of Organization and Economics of Institutions, University of Graz, \\ Universitätsstrasse 15/E4, Graz, Austria \\ michael.kopel@uni-graz.at \\ 2 Department of Political Science, University of Crete, \\ Gallos Campus, 74100 Rethymno, Crete, Greece \\ manasakis@uoc.gr \\ 3 Department of Economics, University of Crete, \\ Gallos Campus, 74100 Rethymno, Crete, Greece \\ petrakis@uoc.gr
}

\begin{abstract}
The present work considers competition between a local firm and a multinational enterprise (MNE). The MNE has a competitive advantage in terms of lower unit costs and plans to enter the local firm's market either through exports or through FDI. The local firm may strategically become "socially responsible" and follow a "doing well by doing good" strategy by investing in socially responsible activities along its value chain. Investments in corporate social responsibility (CSR) increase the responsible firm's equilibrium output and profit as well as consumer surplus and total welfare in its country. The multinational firm's incentives to serve the foreign country through FDI are mitigated in the average consumer's valuation for CSR in the responsible firm's country implying that CSR investments by local firms give space for inward FDI by low-cost multinationals targeting consumers without environmental and social responsibility consciousness. Policy suggestions are also discussed.
\end{abstract}

Keywords: Corporate social responsibility $\cdot$ Multinational firms $\cdot$ Foreign direct investment $\cdot$ Exports $\cdot$ Import tariffs

\section{Introduction}

The core role of multinational enterprises on globalization, mainly through foreign direct investments and international trade (United Nations 2014a; 2014b), gives increasing attention to their practices as well as their resulting market and societal effects. In parallel with the expansion of multinational enterprises, stylized facts and evidence suggest that consumers are increasingly aware of the social and environmental responsibility and footprint of their local firms (Ioannou and Serafeim 2015). In this spirit, Manasakis et al. (2013) cite evidence

(C) The Author(s) 2018

P. Commendatore et al. (eds.), The Economy as a Complex Spatial System,

Springer Proceedings in Complexity, DOI 10.1007/978-3-319-65627-4_10 
suggesting that consumers express a willingness to pay a premium for goods and services produced by socially responsible firms in manufacturing industries, tourism services and agriculture. Within a policy context, the promotion of corporate social responsibility (CSR) has become a top priority in the agenda for sustainable development in many countries and international organizations. Interestingly, when CSR started to become more widespread, its further encouragement became a central policy objective in both the U.S. and the E.U., aiming at the promotion of sustainable growth and competitiveness (European Commission 2001; 2006). ${ }^{1}$ Despite its importance, the statement of Benabou and Tirole (2010) according to which "... little is known about the economics of individual and corporate social responsibility", is still valid. Kitzmueller and Shimshack (2012) further suggest that the field of international CSR warrants greater attention while the preferences and politics that motivate CSR differ substantively across countries.

The present work has been motivated by the apparent interdependence between the increasing trend to invest in CSR and multinational firms' expansion to foreign countries. In this context, we consider two firms located in two different countries, a home country and a foreign country. The firm in the home country plans to become "multinational" and, besides serving its home country's market, serve the foreign country's market too, either through exports or through foreign direct investment (FDI), i.e. establishing a subsidiary in the foreign country. If the multinational firm exports, the exported quantity is subject to a tariff set by the foreign country's government. Alternatively, if the multinational firm chooses FDI, it incurs a fixed set-up cost. The local firm in the foreign country operates under higher unit costs than the multinational firm, but has the option to become "socially responsible". By following such a "doing well by doing good" -strategy it invests in CSR activities along its value chain (Porter and Kramer 2006; 2011) and integrates social and environmental concerns in its business operations "above and beyond" that mandated by its government (Campbell et al. 2012). This strategy meets the preferences of socially conscious consumers for responsible goods whose production processes comply with criteria

${ }^{1}$ The OECD Guidelines for multinational enterprises (OECD 2011) offer governmentbacked recommendations covering business conduct in a wide variety of areas, including employment and industrial relations, human rights, disclosure of financial and non-financial information, environmental issues. The United Nations Global Compact principles (United Nations 2014c) acknowledge the importance of communicating with stakeholders when supporting a precautionary approach to environmental challenges and encourage enterprises to develop sustainability indicators and measure, track, and report progress in incorporating sustainability principles into business practices. 
for social and environmental sustainability (Becchetti et al. 2011). ${ }^{2}$ The products of the local foreign firm and the multinational home firm combine horizontal and vertical differentiation aspects (Häckner 2000; Garella and Petrakis 2008). In particular, socially and environmentally responsible attributes are perceived by socially conscious consumers as a "quality improvement" (see also Manasakis et al. 2013; Liu et al. 2015). In this context, our work addresses the following questions: How do CSR investments by the local firm affect market and societal outcomes in both countries under two different modes of entry, exports and FDI? How does consumers' consciousness for the responsible local firm's product affect the latter outcomes as well as the multinational firm's decision to serve the foreign country through exports or FDI? How does the multinational firm's mode of entry in the foreign country affect consumer surplus and total welfare in the home country and the foreign country?

Our main finding is that the local foreign firm competing against the multinational enterprise seeks to obtain a competitive advantage by strategically engaging in CSR activities that meet the socially conscious consumers' demands. CSR investments increase the responsible local firm's equilibrium output and profit as well as consumer surplus and total welfare in its country, while they decrease the multinational firm's equilibrium output and profits. Under exports, CSR investments reduce total welfare in the multinational firm's home country. We also find that the average consumer's consciousness for the local firm's responsible product increases the tariff, the local firm's CSR effort, output and profit, as well as consumer surplus and total welfare in the foreign country. Yet, it decreases the multinational firm's output and profit, as well as total welfare in the multinational firm's home country. This implies that CSR investments are not welfareenhancing per se. Interestingly, the aforementioned consciousness of consumers reduces the multinational firm's maximum affordable set-up cost for FDI in the foreign country and gives space for attracting inward FDI by low-cost multinationals that target consumers with low preference for environmental and social responsibility. Moreover, consumer surplus and total welfare in the foreign country are always higher under FDI than under exports. The opposite holds for total welfare in the multinational firm's home country where consumer surplus is independent from the multinational's mode of entry into the foreign country. Assuming that within each country, the firm, consumers and the policy maker are the related stakeholders, our findings suggest that the stakeholders' preferences for the mode of entry of the multinational firm in the foreign country are not aligned.

The literature on international trade has studied the question of a multinational firm's optimal mode of entry and its drivers. For example, Ishikawa and

\footnotetext{
${ }^{2}$ In the terminology of Porter and Kramer (2011), CSR activities connect company success with social progress and constitute a profit center for firms while creating value, and for society, by addressing needs and challenges of the firm's stakeholders, such as its employees (investments in health and safety in the workplace), suppliers (support to local suppliers rather than cheaper alternative sources), and the environment (reduction on emissions of pollutants; use of environmentally friendly technologies).
} 
Horiuchi (2012) and Glass and Saggi (2005) relate it to vertically related markets and local sourcing respectively. Sinha (2010) demonstrates the impact of technology licensing on the mode of entry. Mukherjee (2008) and Ma and Zhou (2016) show that FDI and exports can coexist under certain circumstances. None of these papers considers the impact of a local foreign firm's investment in social responsibility, which is the main focus of our paper. Graf and Wirl (2014) investigate if CSR can be used as a strategy to deter entry of a potential competitor. However, they do not deal with a setting of international competition. More specifically, the present work contributes to the scant literature on the interaction between CSR activities and multinational firms. Wang et al. (2012) extend Brander and Spencer (1985), where two foreign firms export a homogenous good in a third country's market. Each firm has the option for a consumer-friendly initiative which is captured by firms pursuing a mixed objective that includes a firm's own profit and consumer surplus. Likewise, Chang et al. (2014) extend Brander and Spencer (1984), where one domestic and one foreign firm produce a homogenous product in the domestic market. Becchetti et al. (2011) consider a standard Hotelling approach where a not-for-profit fair trader enters into a market, with heterogeneous consumers regarding their preferences on social responsibility, where a profit-maximizing producer is already active. We depart from these papers since we formalize the local foreign firm's CSR effort as a particular for-profit investment strategy to compete against a multinational low-cost firm that enters the local foreign market.

The rest of the work is organized as follows. Section 2 presents the model and in Sect. 3 we analyze the multinational firm's possible modes of entry in the foreign country's market. Section 4 studies the multinational's decision between exports and FDI. Finally, Sect. 5 concludes.

\section{The Model}

We consider two firms, denoted 1 and 2. Firm 1 is based in the home country $h$ and firm 2 resides in the foreign country $f$. Firm 1, besides serving the home country $h$, plans to become "multinational" and serve the foreign country $f$, either through exports or by FDI, i.e. through establishing a production facility in country $f$. Firm 2 serves country $f$ 's market solely. We will refer to firm 1 as the multinational firm and Firm 2 as the local firm. If the multinational firm 1 exports to country $f$, the exported quantity is subject to a tariff $t$, set by the importing country's government to maximize country $f$ 's welfare. Following the terminology of Motta and Norman (1996), $t$ is an inverse measure of "market accessibility" and policy changes that increase $t$ "heighten the asymmetry" between the rival firms. ${ }^{3}$ In case of FDI, the multinational firm 1 incurs a fixed

\footnotetext{
${ }^{3}$ Moreover, the commodity exported is subject to a constant transportation unit cost, which, following Fumagalli (2003) and without loss of generality, is normalized to zero. This assumption allows us to economize with the parameters of the model that create unnecessary analytical complications without qualitatively altering our results.
} 
set-up cost $T$, which contains the transaction and construction costs necessary to open a subsidiary in the foreign country (Naylor and Santoni 2003). We assume that the home firm and the multinational firm are both endowed with identical constant returns to scale production technologies. Following Eicher and Kang (2005), Hao and Lahiri (2009), and Mukherjee and Suetrong (2009) we assume that the local firm in country $f$ produces with constant marginal cost denoted by $c$. The multinational firm has a competitive advantage in its production technology, i.e., it is more cost-efficient, with its marginal cost being $c(1-z)$, and $0<z<1$.

We consider that the response of the local firm in country $f$ to the multinational firm's entrance into the foreign market is to become "socially responsible". By following such a "doing well by doing good" strategy, the local firm addresses the preferences of socially conscious consumers for responsible production in country $f$ 's market. This strategy is executed by the local firm through investing in CSR activities along its value chain (Porter and Kramer 2006; 2011) and integrating social and environmental concerns in its business operations. Such concerns include, e.g., purchasing inputs from local suppliers and improving working conditions for employees and point to activities that are " above and beyond" that mandated by government (Campbell et al. 2012; Chambolle and Giraud-Héraud 2005).

On the demand side, following Häckner (2000), Garella and Petrakis (2008), Manasakis et al. (2013) and Liu et al. (2015), the utility function of a representative consumer in country $i$ for $i=h, f$ is:

$$
U_{h}=a q_{h_{1}}-\frac{q_{h_{1}}^{2}}{2}+e_{h}
$$

and

$$
U_{f}=a q_{f_{1}}+\left(a+k_{f} s_{f}\right) q_{f_{2}}-\frac{q_{f_{1}}^{2}+q_{f_{2}}^{2}+2 \gamma q_{f_{1}} q_{f_{2}}}{2}+e_{f}
$$

where $q_{h_{1}}, q_{f_{1}}, q_{f_{2}}$ represent the quantities of firms 1 and 2 bought by the representative consumer in the markets of country $h, f$. The quantities of the "composite good" in country $h, f$ are denoted by $e_{h}, e_{f}$. The composite good's quantity and price are normalized to unity. The parameter $\gamma \in(0,1]$ is a measure of the degree of substitutability between the products offered in the market in country $f$, with $\gamma \rightarrow 0(\gamma=1)$ corresponding to the case of almost independent (homogeneous) goods. Alternatively, $\gamma$ may be interpreted as the intensity of market competition with a higher $\gamma$ representing a higher level of competition.

The variable $s_{f} \geq 0$ represents the level of CSR investments undertaken by the local firm. Investing $s_{f}$ in CSR are assumed to increase the consumers' valuation for the responsible product of the local firm by $k_{f} s_{f}$, where $k_{f} \in$ $[0,1]$ represents the increase of the average consumer's willingness to pay for the product per unit of CSR investment. 
Maximization of (1) and (2) with respect to $q_{I_{i}}$, gives the inverse demand functions:

$$
\begin{aligned}
& P_{h_{1}}=a-q_{h_{1}} \\
& P_{f_{1}}=a-q_{f_{1}}-\gamma q_{f_{2}} ; P_{f_{2}}=a+k_{f} s_{f}-q_{f_{2}}-\gamma q_{f_{1}} .
\end{aligned}
$$

The local firm's CSR investments increase the demand and the average consumer's valuation for its product. Moreover, the local firm's production cost is given by $C_{f}\left(q_{f_{2}}, s_{f}\right)=c\left(1+s_{f}^{2}\right) q_{f_{2}}$, implying that a higher CSR effort level increases its marginal cost at an increasing rate (Manasakis et al. 2013).

If the multinational firm serves the foreign country through exports $(e)$, its profit function is:

$$
\Pi_{1}^{e}=\Pi_{h_{1}}+\Pi_{f_{1}}^{e}=\left[P_{h_{1}}-c(1-z)\right] q_{h_{1}}+\left[P_{f_{1}}-c(1-z)-t\right] q_{f_{1}} .
$$

If the multinational serves the foreign country through FDI $(d)$, its profit function is:

$$
\Pi_{1}^{d}=\Pi_{h_{1}}+\Pi_{f_{1}}^{d}=\left[P_{h_{1}}-c(1-z)\right] q_{h_{1}}+\left[P_{f_{1}}-c(1-z)\right] q_{f_{1}}-T .
$$

The corresponding profit function for the local firm is given by:

$$
\Pi_{2}=\left[P_{f_{2}}-c\left(1+s_{f}^{2}\right)\right] q_{f_{2}}
$$

To guarantee interior solutions under all circumstances, we make the following assumptions regarding the tariff $t$ set by the foreign country's government and the fixed set-up cost $T$ in case of FDI:

Assumption 1: $t<t_{c}:=(2-\gamma)(a-c z)+\frac{\gamma k_{f}^{2}}{4 c}$,

Assumption 2: $T<T_{c}:=\frac{\left[4 c(\gamma-2)(a-2 c z)+\gamma k_{f}^{2}\right]^{2}}{\left[4 c\left(\gamma^{2}-4\right)\right]^{2}}$.

In this context, we consider the following game with observable actions. In the first stage of the game, the government of country $f$ sets the tariff. In the second stage, the multinational firm decides whether to serve country $f$ 's market through exports or FDI. In the third stage, the local firm invests in CSR and the two firms set their quantities for the markets. We solve the game by backward induction and employ Subgame Perfect Nash Equilibrium (SPNE) as a solution concept.

\section{The Multinational Firm's Modes of Entry}

The Multinational Firm Exports to the Foreign Country. We first consider the case where the multinational firm produces in country $h$ and exports its product to the foreign country. In the third stage of the game, firms choose their quantities $q_{h_{1}}, q_{f_{1}}, q_{f_{2}}$ such that their corresponding profits given by (4) and (6) are maximized. Simultaneously, the local firm invests in CSR. 
From the first-order conditions, the firms' output reaction functions for country $f$ 's market can be derived:

$$
\begin{gathered}
R_{f_{1}}^{e}\left(q_{f_{2}}\right)=\frac{1}{2}\left[a-c(1-z)-\gamma q_{f_{2}}-t\right] \\
R_{f_{2}}^{e}\left(q_{f_{1}}\right)=\frac{1}{2}\left[a-c+s_{f}\left(k_{f}-c s_{f}\right)-\gamma q_{f_{1}}\right] .
\end{gathered}
$$

The term $s_{f}\left(k_{f}-c s_{f}\right)$ in (8) captures the two opposing effects of CSR investments. On the one hand, investment $s_{f}$ in CSR increases the local firm's demand by $k_{f} s_{f}$ and its unit cost by $c s_{f}^{2}$. Moreover, as $R_{f_{2}}^{e} / \partial s_{f}=k_{f} / 2-c s_{f}$, the local firm's best response output has an inverted $U$-shaped relation with its CSR efforts, with the maximum attained at $s_{f}=k_{f} / 2 c$. This suggests that the local firm's profit-maximizing level of CSR investments is $s_{f}=k_{f} / 2 c$. This level increases in the average consumer's willingness to pay for this firm's product as well as in the efficiency of the CSR (and output) "production technology" (captured by a lower c). Intuitively, for a relatively low level of CSR efforts, the positive demand effect dominates the negative unit cost effect and $R_{F_{2}}^{e}$ shifts outwards.

Using the optimal level of the local firm's CSR investment and solving the system of first order conditions, we obtain the firm's outputs in country $f$ :

$$
\begin{gathered}
q_{f_{1}}^{e}=\frac{(a-2 c z)(2-\gamma)-\frac{\gamma k_{f}^{2}}{4 c}-2 t}{4-\gamma^{2}} \\
q_{f_{2}}^{e}=\frac{a(2-\gamma)-c[2-\gamma(1-z)]+\frac{k_{f}^{2}}{2 c}+\gamma t}{4-\gamma^{2}} .
\end{gathered}
$$

These output levels highlight the impact of firms' relative comparative advantages in country $f$. More specifically, $\frac{d q_{f_{1}}^{e}}{d z}>0$ and $\frac{d q_{f_{1}}^{e}}{d t}<0$ suggest that the multinational firm's output increases in its relative technological superiority, i.e., as $z \rightarrow 1$, and decreases in the tariff rate $t$. The opposites hold for the local firm.

Given that the multinational firm serves the foreign country though exports, in the first stage of the game the foreign country's government determines its tariff rate $t$ so as to maximize national total welfare given by the sum of consumer surplus, the local firm's profit, and tariff payments:

$$
T W_{f}^{e}(t)=C S_{f}^{e}(t)+\Pi_{f_{2}}^{e}(t)+t q_{f_{1}}^{e}(t) .
$$

The first-order condition determines the socially optimal tariff rate $t=$ $\frac{1}{3}[a-c(1-z)]$. Note that $m_{f}\left(\frac{k_{f}}{a}, \frac{c}{a}\right)=k_{f} / \sqrt{c(a-c)}=\left(k_{f} / a\right) / \sqrt{c / a(1-c / a)}$ is a measure of the average consumer's valuation for CSR activities per unit of market size (adjusted for unit cost relative to market size, $\frac{c}{a}$ ). Moreover, $m_{f}$ is increasing in $\frac{k_{f}}{a}$ and it is U-shaped in $\frac{c}{a}$ reaching its minimum value $\frac{2 k_{f}}{a}$ at $c=\frac{a}{2}$. Its maximum value is equal to $1 . v=z c /(a-c)$ is a measure of the multinational firm's cost advantage adjusted with market size minus unit cost. 
Hence, the equilibrium tariff rate is $t=\frac{1}{3}(a-c)(1+v)$. Using $t$, we obtain firm $i$ 's equilibrium output $q_{f_{i}}^{e}$ and profits $\Pi_{f_{i}}^{e}$, as well as consumer surplus $C S_{f}^{e}$ and total welfare $T W_{f}^{e}$ in the foreign country. The resulting equilibrium outcomes in the home country are $q_{h_{1}}^{e}, \Pi_{h_{1}}^{e}, C S_{h}^{e}$ and $T W_{h}^{e}$. The expressions are provided in Appendix 1a.

\section{The Multinational Firm Establishes a FDI in the Foreign Country.} We now consider the alternative case where the multinational establishes a subsidiary in the foreign country. In this case, in the third stage of the game, each firm chooses its output to maximize its profits given by (5) and (6) respectively and the local firm invests in CSR. From the first-order conditions, the firms' output reaction functions for the market in country $f$ can be obtained:

$$
\begin{gathered}
R_{f_{1}}^{d}\left(q_{f_{2}}\right)=\frac{1}{2}\left[a-c(1-z)-\gamma q_{f_{2}}\right] \\
R_{f_{2}}^{d}\left(q_{f_{1}}\right)=a-c+s_{f}\left(k_{f}-c s_{f}\right)-\gamma q_{f_{1}} .
\end{gathered}
$$

As in the previous case, as long as $s_{f}<k_{f} / 2 c$, the positive demand effect of CSR dominates its negative unit cost effect and the local firm's output reaction function shifts outwards. Using the optimal level of CSR investments, $s_{f}=$ $k_{f} / 2 c$, and solving the system of first order conditions, we obtain each firm's output in the foreign country as

$$
\begin{gathered}
q_{f_{1}}^{d}=\frac{(a-2 c z)(2-\gamma)-\frac{\gamma k_{f}^{2}}{4 c}}{4-\gamma^{2}} \\
q_{f_{2}}^{d}=\frac{a(2-\gamma)-c[2-\gamma(1-z)]+\frac{k_{f}^{2}}{2 c}}{4-\gamma^{2}} .
\end{gathered}
$$

Compared to the previous case of exports, if the multinational firm selects FDI, its firm's cost advantage is further strengthened because it does not face a tariff. Therefore, in case of FDI market competition in the foreign country is fiercer than under exports. The local firm's equilibrium CSR investments are identical to the case of exports. Using $s_{f}$, we obtain firm $i$ 's equilibrium profits $\Pi_{f_{i}}^{d}$, as well as consumer surplus $C S_{f}^{d}$ and total welfare $T W_{f}^{d}$ in the foreign country (expressions are provided in Appendix 1b). Regarding the home country, output and profits are identical to those obtained in case of exports. Consumer surplus and total welfare in the home country are $C S_{h}^{d}$ and $T W_{h}^{d}$ respectively.

\section{Comparing FDI and Exports}

In this section, we compare the results for the case where the multinational firm exports to the foreign country with the results under the assumption that the multinational firm chooses FDI. The following Lemma summarizes the market and societal effects of CSR investments for each mode of entry by the multinational firm in the foreign country. ${ }^{4}$

\footnotetext{
${ }^{4}$ Due to space constraints, the full analysis of the benchmark scenario, where no firm invests in CSR, is not give here but available from the authors upon request.
} 


\section{Lemma 1}

- Under both modes of entry, exports and FDI, CSR investments: (a) increase (decrease) the local firm's (multinational firm's) equilibrium output and profit; (b) increase consumer surplus and total welfare in the foreign country.

- When the multinational firm serves the foreign country's market through exports (FDI), total welfare in the multinational firm's home country is lower when the local firm invests in CSR rather than when it does not (is not affected by the local firm's CSR investments).

The following Proposition summarizes the effects of the firms' relative comparative advantages on the market and societal outcomes for each mode of entry by the multinational firm into the market of the foreign country.

\section{Proposition 1}

- The average consumer's willingness to pay for the local firm's product (higher $\left.m_{f}\right)$ : (a) increases the tariff, the CSR effort, the output and the profit of the local firm, as well as consumer surplus and total welfare in the foreign country; (b) decreases the multinational firm's output and profit, as well as total welfare in the multinational firm's home country.

- The extent of the multinational firm's cost advantage (higher v) increases the tariff, the multinational firm's output and profit as well as consumer surplus and total welfare in both countries.

We can also observe that the multinational firm's quantity in the foreign country is always higher in case of FDI than under exports, i.e., $q_{f_{1}}^{d}>q_{f_{1}}^{e}$. Recall that market competition in country $f$ is fiercer in case of FDI than under exports due to the sunk cost character of FDI investments. In the FDI scenario, the multinational firm avoids the tariff and, hence, has lower marginal production costs. As quantities are in our case strategic substitutes, we can conclude that $q_{f_{2}}^{e}>q_{f_{2}}^{d}$.

Turning our attention to the second stage of the game, we find that the multinational firm will choose to serve the foreign country's market through FDI if $T<T^{c}=\frac{\left[20(1+v)-3 \gamma\left(4+m_{f}^{2}\right)\right](1+v)(a-c)^{2}}{9\left(4-\gamma^{2}\right)^{2}}$. Regarding this critical level of sunk costs, the following observations are in order. First, $\frac{d T^{c}}{d m_{f}}<0$ suggests that an increase in consumers' valuation for the local firm's responsible product reduces the multinational firm's output and profit in country $f$. This, in turn, reduces the maximum affordable set-up cost that the multinational firm can pay for FDI in country $f$, i.e., such an increase in consumers' valuation mitigates the firm's incentive for FDI. Interestingly, $\frac{d T^{c}}{d m_{f}}<0$ further suggests that the multinational firm's maximum affordable set-up cost for FDI in country $f$ is relatively lower than the corresponding level if the local firm does not invest in CSR. Hence, consumers' consciousness for responsible products gives space for attracting inward FDI by low-cost multinationals that target consumers with low willingness to pay for responsible products. Second, $\frac{d T^{c}}{d v}>0$ suggests that the multinational firm's cost advantage increases its maximum affordable set-up cost 
for FDI in country $f$. Third, we find that the local firm prefers the multinational firm to export rather than entering through FDI, i.e., $\Pi_{f_{2}}^{e}>\Pi_{f_{2}}^{d}$ always holds.

The following Proposition summarizes:

\section{Proposition 2}

- The multinational firm will choose to serve the foreign country's market through FDI, if and only if the sunk cost for establishing a production plant in the foreign country is sufficiently low, i.e., $T<T^{c}$.

- The multinational firm's incentives to serve the foreign country through FDI are strengthened in this firm's cost advantage (higher $v$ or higher $z$ ) and mitigated in the average consumer's valuation for CSR (higher $m_{f}$ ) in the foreign country.

Let us now focus on the relative welfare effects of the multinational firm's choice to serve the foreign country's market. First of all, $C S_{h}^{d}=C S_{h}^{e}$ always holds. That is, the multinational firm's mode of entry in country $f$ does not affect country $h$ 's consumer welfare. Yet, total welfare in country $h$ is always higher under exports than under FDI, i.e., $T W_{h}^{e}>T W_{h}^{d}$. The reason is that under FDI the MNE's profit in the foreign country only counts for the foreign country's welfare. This suggests that the home country $h$ 's policy maker could introduce an industrial policy subsidizing exports.

By contrast, consumer surplus in country $f$ is always higher under FDI, i.e., $C S_{f}^{d}>C S_{f}^{e}$ always holds. This happens because market competition in the former case is fiercer than in the latter and hence, total quantity and consumer surplus in country $f$ are relatively higher under FDI. Moreover, total welfare in country $f$ is also higher under FDI than under exports, i.e., $T W_{f}^{e}<T W_{f}^{d}$ always holds. Intuitively, besides consumer surplus which is relatively higher under FDI, the multinational firm's profit in country $f$ in case of FDI exceed the tariff revenues in case of exports to this country, i.e., $\Pi_{f_{1}}^{d}>t q_{f_{1}}^{e}$. Although the local firm's profits are always higher in case of exports than under FDI, the above two positive effects dominate and total welfare in country $f$ is relatively higher under FDI. This suggests that country $f$ 's policy maker could take measures to attract inward FDIs by multinational firms. That is, country $f$ 's policy maker can provide incentives through an industrial policy subsidizing inward FDIs, with the minimum subsidy being equal to the sunk cost needed for the establishment of the multinational firm's production plant in country $f$. The following Proposition summarizes our findings.

\section{Proposition 3}

- Consumer surplus in the multinational firm's country is independent of the multinational firm's mode of entry in the foreign country. Total welfare in the multinational firm's country is always higher in case of exports than under FDI.

- Consumer surplus and total welfare in the foreign country are always higher in case of FDI than under exports. 
The above analysis leads us to two further observations. First, independently of the multinational firm's mode of entry in the foreign country, CSR is welfare-enhancing and policy makers should take measures to promote CSR activities. The policy of the European Commission (2011) is in line with this finding and argues that "...the Commission will step up its cooperation with Member States, partner countries and relevant international fora to promote respect for internationally recognised principles and guidelines, and to foster consistency between them. This approach also requires EU enterprises to renew their efforts to respect such principles and guidelines." See also European Union (2014). Second, it should be noted, however, that the stakeholders' preferences for the multinational firm's mode of entry in the foreign country are not aligned. More specifically, assuming that within each country, the firm, the consumers, and the policy maker are the related stakeholders, we find that the local firm and the multinational country's policy maker would prefer the multinational firm to serve the local firm's country through exports. On the contrary, consumers and the policy maker in the local firm's country would always prefer FDI. These observations reveal that there is space for lobbying over trade and/or industrial policies affecting the mode of entry of multinational firms in foreign countries.

\section{Conclusion}

The present work contributes to the scant literature on the interface between CSR activities to improve the quality or "greenness" of products and the mode of entry of multinational firms into the markets of foreign countries. In our setting, a local firm has the option to become " responsible" and follow a "doing well by doing good" strategy through investing in CSR activities along its value chain. By doing CSR, it tries to achieve a competitive advantage against a multinational rival firm that operates with lower unit costs and plans to enter the local firm's market either through exports or through FDI.

We find that the average consumer's consciousness for the local firm's responsible product increases the tariff, the local firm's CSR effort, output and profit, as well as consumer surplus and total welfare in the foreign country. Yet, it decreases the multinational firm's output and profit, as well as total welfare in the multinational firm's country. Interestingly, the aforementioned consciousness reduces the multinational firm's maximum affordable set-up cost for FDI in the foreign country and gives space for attracting inward FDI by low-cost multinationals that target consumers with low willingness to pay for responsible products.

We also find that there is misalignment of preferences between the stakeholders of the two countries over the multinational firm's mode of entry in the foreign country. This leaves space for lobbying about the relevant trade/industrial policies, an issue that we leave for future research.

\section{Disclosure Statement}

No potential conflict of interest was reported by the authors. 
Aknowledgement. Part of this work was supported by COST Action IS1104 "The EU in the new economic complex geography: models, tools and policy evaluation". Manasakis acknowledges financial support from the University of Crete, Special Account for Research. Full responsibility for all shortcomings is ours.

\section{Appendix}

\section{1a: The Multinational Firm Exports to the Foreign Country}

$$
\begin{aligned}
q_{h_{1}}^{e} & =\frac{1}{2}(\alpha-c)(1+v) ; \Pi_{h_{1}}^{e}=\left(q_{h_{1}}^{e}\right)^{2} \\
q_{f_{1}}^{e} & =\frac{\left[16(1+v)-3 \gamma\left(4+m_{f}^{2}\right)\right](a-c)}{12\left(4-\gamma^{2}\right)} ; \Pi_{f_{1}}^{e}=\left(q_{f_{1}}^{e}\right)^{2} \\
q_{f_{2}}^{e} & =\frac{\left[3\left(4+m_{f}^{2}\right)-4 \gamma(1+v)\right](a-c)}{6\left(4-\gamma^{2}\right)} ; \Pi_{f_{2}}^{e}=\left(q_{f_{2}}^{e}\right)^{2} \\
C S_{h}^{e} & =\frac{1}{2}\left(q_{h_{1}}^{e}\right)^{2} ; T W_{h}^{e}=C S_{h}^{e}+\Pi_{h_{1}}^{e}+\Pi_{f_{1}}^{e} \\
C S_{f}^{e} & =\frac{1}{2}\left[\left(q_{f_{1}}^{e}\right)^{2}+\left(q_{f_{2}}^{e}\right)^{2}+2 \gamma q_{f_{1}}^{e} q_{f_{2}}^{e}\right] ; T W_{f}^{e}=C S_{f}^{e}+\Pi_{f_{2}}^{e}+t q_{f_{1}}^{e}
\end{aligned}
$$

\section{1b: The Multinational Firm Establishes FDI in the Foreign Country}

$$
\begin{aligned}
q_{h_{1}}^{d} & =\frac{1}{2}(\alpha-c)(1+v) ; \Pi_{h_{1}}^{d}=\left(q_{h_{1}}^{d}\right)^{2} \\
q_{f_{1}}^{d} & =\frac{\left[8(1+v)-\gamma\left(4+m_{f}^{2}\right)\right](a-c)}{4\left(4-\gamma^{2}\right)} ; \Pi_{f_{1}}^{d}=\left(q_{f_{1}}^{d}\right)^{2}-T \\
q_{f_{2}}^{d} & =\frac{\left[4+m_{F}^{2}-2 \gamma(1+v)\right](a-c)}{2\left(4-\gamma^{2}\right)} ; \Pi_{f_{2}}^{d}=\left(q_{f_{2}}^{d}\right)^{2} \\
C S_{h}^{d} & =\frac{1}{2}\left(q_{h_{1}}^{d}\right)^{2} ; T W_{h}^{d}=C S_{h}^{d}+\Pi_{h_{1}}^{d} \\
C S_{f}^{d} & =\frac{1}{2}\left[\left(q_{f_{1}}^{d}\right)^{2}+\left(q_{f_{2}}^{d}\right)^{2}+2 \gamma q_{f_{1}}^{d} q_{f_{2}}^{d}\right] ; T W_{f}^{d}=C S_{f}^{d}+\Pi_{f_{1}}^{d}+\Pi_{f_{2}}^{d}
\end{aligned}
$$

\section{References}

Becchetti, L., Federico, G., Nazaria, S.: What to do in globalised economies if global governance is missing? The vicarious role of competition in social responsibility. Int. Rev. Econ. 58(2), 185-211 (2011)

Benabou, R., Tirole, J.: Individual and corporate social responsibility. Economica 77, 1-19 (2010) 
Brander, J.A., Spencer, B.J.: Tariff protection and imperfect competition. In: Kierzkowski, H. (ed.) Monopolistic competition and international trade. Oxford University Press, Oxford (1984)

Brander, J.A., Spencer, B.J.: Export subsidies and international market share rivalry. J. Int. Econ. 18(1-2), 83-100 (1985)

Campbell, T.J., Eden, L., Miller, S.R.: Multinationals and corporate social responsibility in host countries: does distance matter? J. Int. Bus. Stud. 43, 84-106 (2012)

Chambolle, C., Giraud-Héraud, E.: Certification of origin as a non-tariff barrier. Rev. Int. Econ. 13(3), 461-471 (2005)

Chang, Y.M., Chen, H.Y., Wang, L.F.S., Wu, S.J.: Corporate social responsibility and international competition: a welfare analysis. Rev. Int. Econ. 22(3), 625-638 (2014)

Eicher, T., Kang, J.W.: Trade, foreign direct investment or acquisition: optimal entry modes for multinationals. J. Dev. Econ. 77(1), 207-228 (2005)

European Commission, Promoting a European framework for corporate social responsibility. Green Paper and COM, vol. 366, Brussels (2001)

European Commission, Implementing the partnership for growth and jobs: making Europe a pole of excellence on corporate social responsibility. COM, vol. 136, Brussels (2006)

European Commission, A renewed EU strategy 2011-2014 for corporate social responsibility. COM, vol. 681, Brussels (2011)

European Union, Directive 2014/95/EU of the European Parliament and of the Council of 22 October 2014 amending Directive 2013/34/EU as regards disclosure of nonfinancial and diversity information by certain large undertakings and groups. Official Journal of the European Union, vol. L 330/1, 15 November 2014 (2014)

Fumagalli, C.: On the welfare effects of competition for foreign direct investments. Eur. Econ. Rev. 47(6), 963-983 (2003)

Garella, P.G., Petrakis, E.: Minimum quality standards and consumers information. Econ. Theor. 36(2), 283-302 (2008)

Häckner, J.: A note on price and quantity competition in differentiated oligopolies. J. Econ. Theor. 93(2), 233-239 (2000)

Glass, A.J., Saggi, K.: Exporting versus direct investment under local sourcing. Rev. World Econ. 141(4), 627-647 (2005)

Graf, C., Wirl, F.: Corporate social responsibility: a strategic and profitable response to entry? J. Bus. Econ. 84, 917-927 (2014)

Hao, Q., Lahiri, S.: Competition for foreign direct investment: the role of technology and market structure. Int. Rev. Econ. Finance 18, 680-690 (2009)

Ioannou, I., Serafeim, G.: Impact of corporate social responsibility on investment recommendations: analysts' perceptions and shifting institutional logics. Strateg. Manag. J. 36(7), 1053-1081 (2015)

Ishikawa, J., Horiuchi, E.: Strategic foreign direct investment in vertically related markets. Econ. Rec. 88(281), 229-242 (2012)

Kitzmueller, M., Shimshack, J.: Economic perspectives on corporate social responsibility. J. Econ. Lit. 50(1), 51-84 (2012)

Liu, C.-C., Wang, L.F.S., Lee, S.-H.: Strategic environmental corporate social responsibility in a differentiated duopoly market. Econ. Lett. 129, 108-111 (2015)

Ma, J., Zhou, J.: A note on foreign direct investment and exports in vertically differentiated industries. Bull. Econ. Res. (2016). doi:10.1111/boer.12087

Manasakis, C., Mitrokostas, E., Petrakis, E.: Certification of corporate social responsibility activities in oligopolistic markets. Can. J. Econ. 46(1), 282-309 (2013)

Motta, M., Norman, G.: Does economic integration cause foreign direct investment? Int. Econ. Rev. 37, 757-783 (1996) 
Mukherjee, A.: Unionised labour market and strategic decision of a multinational. Econ. J. 118, 1621-1639 (2008)

Mukherjee, A., Suetrong, K.: Privatization, strategic foreign direct investment and host-country welfare. Eur. Econ. Rev. 53, 75-785 (2009)

Naylor, R., Santoni, M.: Foreign direct investment and wage bargaining. J. Int. Trade Econ. Dev. Int. Comp. Rev. 12(1), 1-18 (2003)

OECD, OECD Guidelines for Multinational Enterprises. OECD Publishing (2011)

Porter, M.E., Kramer, M.R.: Strategy and society: the link between competitive advantage and corporate social responsibility. Harvard Bus. Rev. 84, 76-92 (2006)

Porter, M.E., Kramer, M.R.: Creating shared value. Harvard Bus. Rev. 89, 62-77 (2011)

Sinha, U.B.: Strategic licensing, exports FDI, and host country welfare. Oxford Econ. Pap. 62, 114-131 (2010)

United Nations, Trade and development report, Report by the secretariat of the United Nations Conference on Trade and Development, New York and Geneva (2014a)

United Nations, World investment report 2014: Investing in the sustainable development goals (SDGs): An action plan, New York and Geneva (2014b)

United Nations, United Nations Global Compact, New York and Geneva (2014c)

Wang, L.F.S., Wang, Y.C., Zhao, L.: Tariff policy and welfare in an international duopoly with consumer-friendly initiative. Bull. Econ. Res. 64(1), 56-64 (2012)

Open Access This chapter is licensed under the terms of the Creative Commons Attribution 4.0 International License (http://creativecommons.org/licenses/by/4.0/), which permits use, sharing, adaptation, distribution and reproduction in any medium or format, as long as you give appropriate credit to the original author(s) and the source, provide a link to the Creative Commons license and indicate if changes were made.

The images or other third party material in this chapter are included in the chapter's Creative Commons license, unless indicated otherwise in a credit line to the material. If material is not included in the chapter's Creative Commons license and your intended use is not permitted by statutory regulation or exceeds the permitted use, you will need to obtain permission directly from the copyright holder. 